\title{
Kars İlinin Destinasyon İmajı ve Doğu Ekspres'i Deneyimi
}

\author{
DOI: $10.26466 /$ opus.567950
}

*

\author{
Seda Derinalp Çanakçı* - Tuncay Çanakçı* ${ }^{* *}$ Erol Geçgin ${ }^{* * *}$
}

* Dr. Öğr. Üyesi, Kafkas Üniversitesi, Sarıkamış Turizm Fakültesi, Sarıkamış/Kars/Türkiye E-Posta: sedaderinalp@yahoo.com ORCID: 0000-0001-6530-8813

** Dr. Öğr. Üyesi, Kafkas Üniversitesi, Sarıkamış Turizm Fakültesi, Sarıkamış/Kars/Türkiye E-Posta: tuncaycanakci@gmail.com ORCID: 0000-0001-8438-1098

${ }^{* * *}$ Öğr. Gör., Kafkas Üniversitesi, Sarıkamış Meslek Yüksekokulu, Sarıkamış/Kars/Türkiye E-Posta: erolgecgin@hotmail.com ORCID: $\underline{0000-0001-8375-9343}$

\section{Öz}

Bu araştırma, Kars ilini ziyaret eden ve Doğu Ekspres'i ile ayrılan yerli turistler aracıllğı ile Kars ilinin destinasyon imajını ve turistlerin Doğu Ekspres'i deneyimleri ile ilgili düşüncelerini ortaya koymak amacıyla tasarlanmıştır. Araştırmada örneklem seçimi olarak olasılığa dayalı olmayan örnekleme tekniklerinden kolayda örnekleme yönteminin kullanılması tercih edilmiştir. Anketin uygulanma sürecinde yerli turistler ile yüz yüze temas edilmiştir. Uygulama sonucu toplam 388 adet kullanilabilir anket elde edilmiştir. Araştırmaya katılan yerli turistler destinasyon imajını; turistik işletmelerin imajı, bilgilendirme ofisleri, Doğu Ekspres'i, yerel halk imajı, şehir imajı ve ulaşım olanakları olmak üzere altı faktörde algılamışlardır. Kars'ı ziyaret eden yerli turistlerin destinasyon imajı algılarının demografik özelliklerine göre farklhlı gösterip göstermediğinin belirlenmesi amactyla yapılan $t$-testi ve varyans analizleri sonucuna göre cinsiyet, yaş grubu ve eğitim durumu değişkenlerine göre anlaml farklilıklara rastlanılmıştır.Yerli turistlerin en çok katıldıkları turistik aktivitelerin başında ise, Doğu Ekspres'i deneyimi, Ani Antik Kent ziyareti ve Çıldır gölü gelmektedir. Önem derecesine göre Halk Oyunları son sırada yer almaktadır.

Anahtar Kelimeler: Destinasyon imajı, Doğu Ekspres'i, Kars. 


\title{
Destination Image of Kars Province and Orient Express Experience
}

\begin{abstract}
This research has been designed to reveal the image of the province of Kars and the opinions of the tourists about the expriences of the Orient Express via local tourists visiting Kars and departing with Orient Express. In the research, it was preferred to use sampling method which is not based on probability as sampling choice. During the implementation of the survey, local tourists were contacted face to face. A total of 388 available surveys were obtained. Local tourists who participated in the research were able to identify the destination image in six factors; touristic enterprises, information offices, Orient Express, local public image, city image and transportation facilities. According to the results of t-test and analysis of variance, significant differences were found according to the variables of gender, age group and educational status in order to determine whether the destination image of the local tourists visiting Kars differ according to their demographic characteristics. The most popular local tourist activities are Orient Express experience, the Ani Ancient City visit and Cildir lake. According to their importance, Folk Dance is the last place.
\end{abstract}

Keywords: Destination image, Orient Express, Kars. 


\section{Giriş}

Ülkelerin gelişmesi ve kalkınmasında önemli bir yere sahip olan turizm endüstrisi, doğrudan veya dolaylı olarak etkilediği birçok endüstri ile birlikte ekonomik canlılığın en önemli göstergelerinden birisini oluşturmaktadır. Dolayısıyla, gerek turizm yatırımclarının gerek ise turistlerin turizme olan ilgi ve beklentileri son yıllarda önemli bir oranda artış göstermektedir.

Turistlerin farklı istek ve beklentileri ile şekillenen turizm endüstrisinin, her destinasyonun pazarlanmasında değişen tüketici isteklerine yönelik hizmet üretimi sağlamak ve turistlerin ilgisini çekecek çekiciliklere yer vermesi gerekmektedir. Alt yapısı güçlü, turistik yatırımları yeterli, olumlu bir imaj taşıyan, rakiplerinden farklı ürünlere ve alternatiflere sahip destinasyonlar pazardan daha büyük pay elde etmektedirler. Böylece destinasyonların pazarlanmasında ve turistlerin destinasyona yönelik algılarında imaj önemli bir faktör olarak ortaya çıkmaktadır. Birçok farklı değişken tarafından etkilenebilen destinasyon imajı bölge kaynaklarının etkin olarak yönetilerek ve korunarak turistlerin beklentileri doğrultusunda sürdürülebilir şekilde sunulması gerekmektedir.

Bu çalışmanın amacı, Kars'ı ziyaret eden ve Doğu Ekspres'i ile ayrılan yerli turistler aracılığı ile Kars'ın destinasyon imajını ve turistlerin Doğu Ekspres'i deneyimleri ile ilgili düşüncelerini ortaya koymaktır. Çalışmada kısaca destinasyon imajı literatürüne yer verilmiştir. Ardından araştırmanın amacı ve yöntemi, veri toplama aracı, evren ve örneklem, verilerin analizi ve bulgularına yer verilerek sonuç ve öneriler ile sonlandırılmıştır.

\section{Destinasyon İmajı}

Destinasyon kavramının tanımı geçmişten günümüze gelinerek birçok defa yapılmıştır. Destinasyon, bir ada, ülke ve kasaba gibi coğrafik alanlar olarak tanımlanırken, bir başka tanıma göre insanların belli bir etkinlikte bulunmak için seyahat ettikleri ve konakladıkları yer olarak tanımlanmaktadır (Davidson ve Maitland, 1997; Hall, 2000). Bir başka tanıma göre destinasyon, turistlerin ihtiyaçlarını karşıladıkları etkinlik noktası, turizm 
hareketlerinde gidilecek yer, son varış noktası, kişinin gitmek istediği seçilmiş veya belirlenmiş yerdir (Cooper, Fletcher, Gilbert, Shepherd ve Wanhill, 1998).

İmaj, geniş kapsamlı ve karmaşık bir kavramdır. Bu nedenle imaj kavramının çok sayıda tanımı yer almaktadır (Yaraşlı, 2007, s.4). İmajın, bir yer veya ürün hakkında kişi ya da grupların bilgi, izlenim, önyargı ve görüşleri olarak tanımlanması mümkündür (Tolungüç, 1992, s.11). Başka bir tanıma göre imaj, bilgilenme sürecinin sonunda ulaşılan imge olarak tanımlanmaktadır. Ayrıca imaj, kişiye yardım eden, duyu organlarımız ile hissettiğimiz bir şey ile ilgili zihnimizde oluşan duygular ve bilgiler olarak da tanımlanabilir (Öter ve Özdoğan, 2005, s.129; Umur, 2016, s.273).

Turizm açısından ele alındığında imaj, sunulan mal ve hizmetler bütününün insanlar tarafından algılanması sonucunda ortaya çıkan bir kavram olarak görülmektedir (Kıycı, 2010, s.24). Turizmde kullanılan imaj kavramı "destinasyon imajı" olarak ifade edilmektedir (Tosun ve Temizkan, 2004, s.350).

Destinasyon imajı, destinasyonun sahip olduğu niteliklere yönelik insanların bireysel algılarının daha bütüncül bir yapı oluşturmasıyla ortaya çıkmaktadır (Choi, Chan ve Wu, 1999,s.361). Dolayısıyla destinasyon imajı, kişilerin bir destinasyon hakkında sahip oldukları fikirlerin, inançların ve izlenimlerin toplamı olarak ifade edilebilmektedir (Hunt, 1975; Baloğulu ve McCleary, 1999, s.870).

Bireyin zihninde oluşan bazı izlenimler üzerine kurulan imaj oluşumu, destinasyon imajı olarak bakıldığında bu izlenimler; tanıtım kaynakları (seyahat broşürleri, afişler), başkalarının düşünceleri (aile, arkadaş, seyahat acenteleri), medya (gazete, dergi, televizyon, kitap, filmler) gibi pek çok kaynaktan gelmektedir. Bu izlenimler, destinasyonun ziyaret edilmesiyle birlikte, edinilen bilgi ve deneyim nedeniyle imaj etkilenmekte ve değişime uğramaktadır (Echtner ve Ritchie 2003, s.38). Sözü geçen etkenler göz önüne alındığında Kars ili son yıllarda medyada yer alan haberler ve Kars'a yolculuk eden turistlerin ulaşım aracı olarak Doğu Ekspres'ini tercih etmesi ve bu seyahate dair yapılan paylaşımların artması sonucu henüz Kars'ı ziyaret etmeyen turistlerin ilgisini çekmektedir.

Diğer ulaşım sistemleri ile kıyaslandığında demiryolu ulaşımını turizm açısından çekici kılan bazı özellikleri bulunmaktadır. Fazla sayıda 
yolcu taşıyabilmesi, rahat olması, tren içinde dolaşma imkanının bulunması, yataklı odalarda geceleme imkanın bulunması ve tren içinde yemeiçme hizmetinin veriliyor olması turistlerin demiryolu ulaşım sistemini tercih nedenlerindendir (Doğaner, 1998). Son varış noktası Kars ili olan Doğu Ekspres treninin turistler açısından tercih nedenleri arasında yukarıda sıralanan nedenler dışında, tren geçiş güzergahının eşsiz manzaraya sahip olması ve 24-26 saat arası seyahat süresi boyunca yolcular arasında kurulan sosyal iletişimin yolculuğu eğlenceli hale getirmesi sayılabilmektedir.

\section{Araştırma Yöntemi}

\section{Araştırmanın Amacı ve Yöntemi}

Bu araştırma, Kars'ı ziyaret eden ve Doğu Ekspres'i ile ayrılan yerli turistler aracılığı ile Kars'ın destinasyon imajını ve turistlerin Doğu Ekspres'i deneyimleri ile ilgili düşüncelerini ortaya koymak amacıyla tasarlanmıştır. Yerli turistlerin, kültür amaçlı ziyaret ettikleri Kars ili, eşsiz doğal güzelliklerinin yanı sıra, tarihi yapıları, farklı mutfak kültürü ve Doğu Ekspres'i ulaşım imkanının bulunması Kars turizmine yönelik önemli bir çekim niteliği taşımaktadır. Bu doğrultuda araştırmanın iki temel araştırma sorusu bulunmaktadır. Bunlar: (1) Turistlerin Kars' in destinasyon imajına yönelik algıları nelerdir? (2) Doğu Ekspres'i ile seyahat etmek Kars ziyaretinde turistlerin beklentilerini karşılamakta mıdır? Temel araştırma sorularının yanı sıra, destinasyon imajının demografik özelliklere göre farklılıkları ve en çok katıldıkları turistik aktivitelerin neler olduğu da çalışmada yanıtları aranan sorular arasındadır.

\section{Veri Toplama Aracı}

Araştırmada veriler, alan yazından yararlanılarak geliştirilen bir anket ile toplanmıştır. Ankette yer alan sorular, iki bölümden oluşmaktadır. Birinci bölümde yerli turistlerin demografik özelliklerine ilişkin sorular yer alırken, ikinci bölümde literatürden (Choi vd., 1999; Hui ve Wan, 2003; Beerli ve Martim, 2004; Kim ve Eves, 2012; Kim, Eves ve Scarles, 2013; Kodaş, 2013; Benli ve Yenipınar, 2018) faydalanılarak araştırmacılar tarafından 
geliştirilmiş destinasyon imajı ölçeği yer almaktadır. Turistlerin ankette yer alan sorulara ilişkin katılım düzeyleri "kesinlikle katılmıyorum" (1), "katılmıyorum" (2), "ne katılıyorum/ ne katılmıyorum" (3), "katılıyorum" (4), "kesinlikle katılıyorum" (5) seçeneklerinden birini seçerek belirtmeleri istenmiştir. Ankette yer alan soruların anlaşılırlığı açısından 12-21 Aralık 2017 tarihleri arasında Kars'ı ziyaret eden 58 yerli turist üzerinde ön test yapılmıştır. Ön test sonucu Cronbach's Alpha değeri 0,857 olarak ortaya çıkmıştır.

\section{Evren ve Örneklem}

Araştırmanın evrenini, Kars'ı ziyaret edip Doğu Ekspres'i ile ayrılan yerli turistler oluşturmaktadır. Anketin uygulanması 24 Ocak ve 12 Şubat 2018 tarihlerinde araştırmacılar tarafından Doğu Ekspres Treni ile seyahat esnasında gerçekleşmiştir. Anketin uygulanma sürecinde yerli turistler ile yüz yüze temas kurulmuştur. Uygulama sonucu toplam 388 adet kullanılabilir anket elde edilmiştir.

Araştırmada örneklem seçimi olarak olasılığa dayalı olmayan örnekleme tekniklerinden kolayda örnekleme yönteminin kullanılması tercih edilmiştir. Kolayda örnekleme tekniği ankete cevap veren herkesin örnekleme dahil edilebilmesi esasına dayanmaktadır (Altunışık, Coşkun, Bayraktaroğlu ve Yıldırım, 2012, s.139-140). Bu tekniğin tercih edilmesindeki amaç zaman tasarrufunu sağlayarak, ekonomik bir şekilde veri elde edilmesidir (Nakip, 2006, s.204).

\section{Verilerin Analizi}

Veri analiz sürecinde, verilerin faktör analizine uygun olup olmadığını belirlemek amacıyla ölçeğe normal dağılım testi ve sapan analizi uygulanmıştır. Verilerin normal dağılıma uygunluğunun incelenmesi için çarpıklık (skewness) ve basıklık (kurtosis) testlerinden yararlanılmıştır. Ölçeğin çarpıklık ve basıklık değerlerinin \pm 3 aralığında yer aldığı tespit edilmiş ve normallik açısından uygun dağılım gösterdiği belirlenmiştir.

Ankette yer alan destinasyon imajı ölçeği için kayıp veri analizi yapılmış ve ölçekte en fazla \%0,6 kayıp veri ortaya çıkmıştır. Kayıp verilerde 
çok önemli ölçüde rastgelelik olması sebebiyle, ölçekteki kayıp veriler, ilgili maddenin ortalaması kullanılarak tamamlanmıştır (Kalaycl, 2010, s.21-27). Araştırmada destinasyon imajı ölçeğinin tamamı güvenirlik analizine alınmış ve Cronbach's Alpha katsayısı 0,818 olarak bulunmuştur. Bu değer ölçeğin yüksek derecede güvenilir olduğunu göstermektedir.

\section{Bulgular}

Araştırmaya katılanların demografik özelliklerine ilişkin bulgular Tablo 1'de sunulmaktadır. Kars'ı ziyaret edip Doğu Ekspres'i ile ayrılan yerli turistlerin $\% 51,8$ 'inin kadın $\% 48,2$ 'sinin erkek olduğu belirlenmiştir..

Tablo 1. Katılımcıların Demografik Özelliklerine Göre Dağılımı

\begin{tabular}{|c|c|c|c|c|c|}
\hline Değişken & $\mathbf{F}$ & $\%$ & Değişken & $\mathbf{F}$ & $\%$ \\
\hline \multirow{2}{*}{ Cinsiyet } & & & \multicolumn{3}{|l|}{ Kullanılan Ulaşım Aracı } \\
\hline & & & Otobüs & 23 & 5,9 \\
\hline Kadın & 201 & 51,8 & Tren & 206 & 53,1 \\
\hline Erkek & 187 & 48,2 & Uçak & 155 & 39,9 \\
\hline \multirow[t]{2}{*}{ Toplam } & 388 & 100,0 & Otomobil & 4 & 1,0 \\
\hline & & & Toplam & 388 & 100,0 \\
\hline Kalış Süresi & & & Kars'1 Ziyaret Sayısı & & \\
\hline Günü birlik & 12 & 3,1 & İlk kez & 283 & 72,9 \\
\hline 1-2 gece & 178 & 45,9 & $2-3$ aras 1 & 42 & 10,8 \\
\hline 3-4 gece & 136 & 35,1 & $4-5$ aras & 6 & 1,5 \\
\hline 5 gece ve üzeri & 62 & 16,0 & 6 ve üzeri & 57 & 14,7 \\
\hline Toplam & 388 & 100,0 & Toplam & 388 & 100,0 \\
\hline Eğitim Durumu & & & Toplam Harcama & & \\
\hline Ortaokul & 3 & 0,8 & $0-500 \mathrm{TL}$ & 141 & 36,3 \\
\hline Lise & 55 & 14,2 & $501-1500 \mathrm{TL}$ & 142 & 36,6 \\
\hline Önlisans & 26 & 6,7 & $1501-2500 \mathrm{TL}$ & 78 & 20,1 \\
\hline Lisans & 236 & 60,8 & $2501-3500 \mathrm{TL}$ & 8 & 2,1 \\
\hline Lisansüstü & 68 & 17,5 & 3501 TL ve üzeri & 19 & 4,9 \\
\hline Toplam & 388 & 100,0 & Toplam & 388 & 100,0 \\
\hline \multicolumn{6}{|l|}{ Yaş Grubu } \\
\hline 25 yaş ve altı & 205 & 52,8 & & & \\
\hline $26-30$ yaş arası & 48 & 12,4 & & & \\
\hline $31-35$ yaş arası & 38 & 9,8 & & & \\
\hline $36-40$ yaş aras 1 & 16 & 4,1 & & & \\
\hline $41-45$ yaş arası & 13 & 3,4 & & & \\
\hline 46 yaş ve üzeri & 68 & 17,5 & & & \\
\hline Toplam & 388 & 100,0 & & & \\
\hline
\end{tabular}


Araştırmaya katılanların yaş grupları incelendiğinde en büyük oranın $\% 52,8$ ile "25 yaş ve altı" grubundaki yerli turistlere ait olduğu belirlenmiştir. Katılımcıların \%60,8'i ise lisans mezunu turistlerden oluşmaktadır.

Araştırmaya katılan yerli turistlerin \%53,1'i ulaşım aracı olarak Doğu Ekspres Tren'ini kullanmış, \%72,9'u Kars'ı ilk kez ziyaret etmiş ve \%45,9'u 1-2 gece konaklamışlardır. Yerli turistlerin yaptıkları harcamalar dikkate alındığında \%36,6 oranında 501-1500 TL harcama yapıldığı görülürken $\% 36,3$ benzer oranında 0-500 TL harcama yapıldığ 1 sonucu ortaya çıkmıştir.

Tablo 2 katılımcıların geldikleri illere göre dağılımını göstermektedir. Buna göre Kars'1 ziyaret eden yerli ziyaretçiler büyük oranda İstanbul $(\% 31,2)$ ve Ankara $(\% 20,4)^{\prime}$ dan gelmektedirler.

Tablo 2. Katılımcıların Geldikleri İllere Göre Dağılımı

\begin{tabular}{lll}
\hline İller & $\mathbf{N}$ & $\mathbf{\%}$ \\
\hline İstanbul & 121 & 31,2 \\
Ankara & 79 & 20,4 \\
Erzurum & 31 & 8 \\
İzmir & 23 & 5,9 \\
Adana & 15 & 3,9 \\
Manisa & 15 & 4,6 \\
Bursa & 14 & 3,6 \\
Erzincan & 14 & 3,6 \\
Mersin & 12 & 3,1 \\
Eskişehir & 9 & 2,3 \\
İzmit & 9 & 2,3 \\
Kayseri & 9 & 2,3 \\
Diğer İller & 37 & 9,7 \\
\hline
\end{tabular}

Tablo 3 katılımcıların önem derecesine göre katıldıkları turistik aktiviteleri göstermektedir. Buna göre Kars ziyaretinde bulunan yerli turistlerin en çok önemsedikleri turistik aktivitelerin başında Doğu Ekspres'i deneyimi, daha sonra ise Ani Antik Kenti ziyareti, Çıldır Gölü ve Baltık mimarisi ziyaretleri gelmektedir. Önem derecesine göre Halk Oyunları son s1rada yer almaktadır. Çalışmada veri setinin açılayıcı faktör analizi için uygunluğu Kaiser-Meyer- Olkin örneklem yeterliliği ölçütü ile belirlenmiştir. Kalaycı (2010, s.322) analizlerin doğru sonuçlar verebilmesi için KMO oranının 0,50'nin üzerinde olması gerektiğini savunmaktadır. Oran 
ne kadar yüksek olursa veri seti faktör analizi yapmak için o kadar iyidir denilebilir.

Tablo 3. Katılımcıların Önem Derecesine Göre Katıldıkları Turistik Aktiviteler

\begin{tabular}{lllllllllll}
\hline & $\mathbf{1}$ & \multicolumn{3}{c}{$\mathbf{2}$} & $\mathbf{3}$ & & $\mathbf{4}$ & \multicolumn{3}{c}{$\mathbf{5}$} \\
\cline { 2 - 11 } & $\mathbf{N}$ & $\mathbf{\%}$ & $\mathbf{N}$ & $\mathbf{\%}$ & $\mathbf{N}$ & $\mathbf{\%}$ & $\mathbf{N}$ & $\mathbf{\%}$ & $\mathbf{N}$ & $\mathbf{\%}$ \\
\hline Ani Antik Kenti & 83 & 21,4 & 101 & 24,1 & 87 & 22,4 & 38 & 9,8 & 23 & 5,9 \\
\hline Baltık Mimarisi & 11 & 2,8 & 32 & 8,2 & 67 & 17,3 & 85 & 24,9 & 54 & 13,9 \\
\hline Çlldır Gölü & 48 & 12,4 & 87 & 21,3 & 117 & 30,3 & 43 & 11,1 & 24 & 6,2 \\
\hline Halk Oyunu & - & - & - & - & 3 & 0,8 & 16 & 4,1 & 26 & 6,7 \\
\hline Kayak & 31 & 8,0 & 55 & 17,3 & 22 & 5,7 & 32 & 8,2 & 42 & 11,1 \\
\hline Müze Ziyareti & 4 & 1,0 & 9 & 2,3 & 10 & 2,6 & 26 & 6,7 & 21 & 5,4 \\
\hline Şehitlik Ziyareti & 39 & 10,1 & 31 & 8,0 & 30 & 7,7 & 24 & 6,2 & 21 & 5,4 \\
\hline $\begin{array}{l}\text { Doğu Ekspres'i } \\
\text { Deneyimi }\end{array}$ & 171 & 44,1 & 51 & 13,1 & 29 & 7,5 & 23 & 5,9 & 34 & 8,8 \\
\hline Gastronomi & 1 & 0,3 & 9 & 2,3 & 35 & 9,0 & 66 & 17,0 & 71 & 18,3 \\
\hline
\end{tabular}

Diğer taraftan yapılan açılayıcı faktör analizlerinde faktörleştirme tekniği olarak temel bileşenler analizi (principal components analysis) kullanılmıştır. Analizlerin daha iyi yorumlanabilmesi için faktör varyanslarının maksimum olmasını sağlayacak şekilde döndürme yapan dik döndürme yöntemlerinden maksimum değişkenlik (varimax) tercih edilmiştir (Çokluk, Şekercioğlu ve Büyüköztürk, 2012, s. 203). Son olarak, faktör analizinde öz değeri bir ve birin üzerinde olan faktörler kararlı sayıldığından öz değeri birden büyük olan ve faktör yükü 0,40'ın üzerinde olan maddeler dikkate alınmıştır (Çokluk vd., 2012,s.192).

Tablo 4 destinasyon imajı ölçeğinin faktör analizi sonuçlarını göstermektedir. Faktör analizi sonuçları Kars'1 ziyaret eden yerli turistlerin destinasyon imajı algılarının altı başlıkta incelendiğini göstermekte, aynı zamanda çalışmanın birinci ve ikinci araştırma soruları da yanıtlanmış olmaktadır. Maddelerin dağıldığı faktör boyutları incelendiğinde, yerli turistlerin Kars destinasyonu imajına yönelik algılarının; "Turistik işletmelerin imajı", "Bilgilendirme ofisleri”, "Doğu Ekspres'i", "Yerel halk imajı”, "Şehir imajı" ve "Ulaşım olanakları" ile ilişkilendirdikleri görülmektedir. Faktör boyutlarına göre çıan ortalamalar göz önüne alındığında "Bilgilendirme ofisleri" ve " Ulaşım olanakları" hariç diğer tüm faktör ortalamalarının yüksek olduğu, buna göre Kars'ı ziyaret eden yerli turistlerin Kars destinasyonuna yönelik algılarının olumlu olduğu söylenebilmektedir. 
Tablo 4. Destinasyon İmajı Faktör Analizi Sonuçları

\begin{tabular}{|c|c|c|c|c|c|}
\hline Destinasyon İmajı & $\begin{array}{l}\text { Faktör } \\
\text { Yükü }\end{array}$ & $\begin{array}{l}\text { Öz } \\
\text { Değer }\end{array}$ & $\begin{array}{l}\text { Var- } \\
\text { yans }\end{array}$ & $\begin{array}{l}\text { Orta- } \\
\text { lama }\end{array}$ & $\begin{array}{l}\text { Güve- } \\
\text { nirlik }\end{array}$ \\
\hline $\begin{array}{l}\text { Turistik İşletmelerin İmajı } \\
\text { (5 madde) }\end{array}$ & & 2,642 & 11,489 & 3,144 & ,768 \\
\hline Her bütçeye uygun oteller yer almaktadır & 837 & & & & \\
\hline $\begin{array}{l}\text { Konaklama tesislerinin sayısı ve } \\
\text { kalitesi yeterlidir }\end{array}$ & ,726 & & & & \\
\hline $\begin{array}{l}\text { Çeşitli sanatsal ve kültürel etkinlikler } \\
\text { yapılmaktadır }\end{array}$ & ,626 & & & & \\
\hline $\begin{array}{l}\text { Turistlerin akşamları eğlenmesi } \\
\text { için yeterince işletme vardır }\end{array}$ &, 577 & & & & \\
\hline Yiyecek içecek işletmeleri yeterlidir &, 471 & & & & \\
\hline Bilgilendirme Ofisleri (3 madde) & & 2,561 & 11,135 & 2,522 & 780 \\
\hline $\begin{array}{l}\text { Turistlerin bilgi edineceği ofisler } \\
\text { yeterli sayıdadır }\end{array}$ & ,833 & & & & \\
\hline Turist bilgi ofislerine ulaşım kolaydır & ,822 & & & & \\
\hline $\begin{array}{l}\text { Turistlerin yönlendirilmesi ve } \\
\text { bilgilendirmesi yeterlidir }\end{array}$ & ,726 & & & & \\
\hline Doğu Ekspres (4 madde) & & 2,361 & 10,263 & 3,941 & 748 \\
\hline $\begin{array}{l}\text { Doğu Ekspres'i bir seyahatten } \\
\text { beklentilerime cevap vermiştir }\end{array}$ & ,772 & & & & \\
\hline $\begin{array}{l}\text { Doğu Ekspres'ini bir sonraki } \\
\text { seyahatimde tekrar kullanmak isterim }\end{array}$ & 732 & & & & \\
\hline $\begin{array}{l}\text { Doğu Ekspres'inin hizmet } \\
\text { kalitesi yeterlidir }\end{array}$ & 687 & & & & \\
\hline $\begin{array}{l}\text { Doğu Ekspres'i temizlik ve hijyen } \\
\text { açısından yeterlidir }\end{array}$ & ,656 & & & & \\
\hline Yerel Halk İmajı (4 madde) & & 2,314 & 10,062 & 3,941 & ,750 \\
\hline Yerel halk yardım severdir & 787 & & & & \\
\hline $\begin{array}{l}\text { Esnaf, turistlere karşı ilgili ve güler yüzlü- } \\
\text { dür }\end{array}$ & ,716 & & & & \\
\hline Yerel halk misafirperverdir & 693 & & & & \\
\hline $\begin{array}{l}\text { Görevliler gelen turiste ilgileri } \\
\text { yeterlidir }\end{array}$ & ,411 & & & & \\
\hline Şehir İmajı (4 madde) & & 2,051 & 8,918 & 3,546 & ,704 \\
\hline Şehir temizdir & ,701 & & & & \\
\hline Şehir güvenlidir & 661 & & & & \\
\hline $\begin{array}{l}\text { Şehirde alışveriş olanakları yeterli } \\
\text { düzeydedir }\end{array}$ &, 545 & & & & \\
\hline Şehirde ulaşım rahat ve kolaydır &, 507 & & & & \\
\hline Ulaşım Olanakları (3 madde) & & 1,897 & 8,897 & 2,672 & 664 \\
\hline Ulaşım ekonomiktir & 789 & & & & \\
\hline Ulaşım imkanları yeterlidir & 755 & & & & \\
\hline Şehirlerden turistik yerlere ulaşım yeterlidir &, 519 & & & & \\
\hline
\end{tabular}


Diğer taraftan, Doğu Ekspres'i ile seyahat etmek Kars ziyaretinde yerli turistlerin beklentilerini karşıladığı çıkan ortalama sonucu ile görülmektedir. Kars'ı ziyaret eden yerli turistlerin cinsiyetlerine göre anlamlı farklılık gösterip göstermediği bağımsız çift örneklem t- testi ile araştırılmıştır. Yapılan t-testi sonuçları Tablo 5'te sunulmaktadır. Destinasyon imajı değişkenine göre; "yerel halk imajı" ve " şehir imajı" tercihlerine verilen puanlar arasında anlamlı farklılıklara rastlanılmıştır.

Tablo 5. Cinsiyet Değişkenine Göre Destinasyon İmajının T-testi Sonuçları

\begin{tabular}{llllll}
\hline Destinasyon İmajı & Cinsiyet & $\mathbf{n}$ & Ort. & t-Değeri & Anlam Düzeyi \\
\hline \multirow{2}{*}{ Yerel Halk İmajı } & Kadın & 201 & 3,7600 & \multirow{2}{*}{2,804} & \multirow{2}{*}{005} \\
& Erkek & 187 & 3,5134 & & \multirow{2}{*}{029} \\
Şehir İmajı & Kadın & 201 & 3,3445 & \multirow{2}{*}{2,185} & \multirow{2}{*}{ Erkek } \\
\hline
\end{tabular}

Tablo 6 yaş değişkenine gore anlamlı farklılık gösterip göstermediğinin sonuçlarını göstermektedir. Tek yönlü varyans analizi sonucuna göre yerli turistlerin "turistik işletmeler", "bilgilendirme ofisi", "Doğu Ekspres'i", "yerel halk imaj1" ve "şehir imaj1" tercihlerinde yaş değişkenine göre verilen puanların arasında anlamlı farklılıklara rastlanılmıştır.

Tablo 6. Yaş Grupları Değişkenine Göre Destinasyon Imajına Uygulanan ANOVA Analizi

\begin{tabular}{|c|c|c|c|c|c|}
\hline Destinasyon İmajı & Yaş Grubu & $\mathbf{N}$ & Ort. & Std. Sapma & F Değeri \\
\hline \multirow{4}{*}{ Turistik İşletmeler } & 25 yaş ve altı & 205 & 3,2839 & 79285 & \multirow{4}{*}{8,320} \\
\hline & $26-30$ yaş arası & 48 & 2,8917 & ,82303 & \\
\hline & $31-40$ yaş arası & 54 & 2,7407 & 66801 & \\
\hline & 41 yaş ve üzeri & 81 & 3,2123 & ,90793 & \\
\hline \multirow{4}{*}{ Bilgilendirme Ofisleri } & 25 yaş ve altı & 205 & 2,9415 & 1,04883 & \multirow{4}{*}{3,024} \\
\hline & $26-30$ yaş arası & 48 & 2,6944 & 84449 & \\
\hline & $31-40$ yaş arası & 54 & 2,5123 & ,87287 & \\
\hline & 41 yaş ve üzeri & 81 & 2,8025 & ,99412 & \\
\hline \multirow{4}{*}{ Doğu Ekspres } & 25 yaş ve altı & 205 & 3,7695 & ,83188 & \multirow{4}{*}{9,367} \\
\hline & 26-30 yaş arası & 48 & 3,6510 & ,70284 & \\
\hline & $31-40$ yaş arası & 54 & 3,3796 & ,81949 & \\
\hline & 41 yaş ve üzeri & 81 & 3,2623 & ,74257 & \\
\hline \multirow{4}{*}{ Yerel Halk İmajı } & 25 yaş ve altı & 205 & 3,7585 & 87250 & \multirow{4}{*}{4,184} \\
\hline & $26-30$ yaş arası & 48 & 3,6667 & ,91578 & \\
\hline & $31-40$ yaş arası & 54 & 3,3148 & ,94443 & \\
\hline & 41 yaş ve üzeri & 81 & 3,5463 & ,73857 & \\
\hline \multirow{4}{*}{ Şehir İmajı } & 25 yaş ve altı & 205 & 3,3695 & 86339 & \multirow{4}{*}{3,028} \\
\hline & $26-30$ yaş arası & 48 & 3,1458 & ,91214 & \\
\hline & $31-40$ yaş arası & 54 & 3,0463 & 76491 & \\
\hline & 41 yaş ve üzeri & 81 & 3,1759 & 67482 & \\
\hline
\end{tabular}


Tablo 7. Eğitim Durumu Değişkenine Göre Destinasyon Imajına Uygulanan ANOVA Analizi

\begin{tabular}{llllll}
\hline $\begin{array}{l}\text { Destinasyon } \\
\text { İmaji }\end{array}$ & Yaş Grubu & $\mathbf{N}$ & Ort. & Std. Sapma & F Değeri \\
\hline \multirow{3}{*}{$\begin{array}{l}\text { Turistik } \\
\text { İşletmeler }\end{array}$} & Ortaokul ve Lise & 58 & 3,3759 &, 95593 & \\
& Önlisans & 47 & 3,0511 &, 90551 & \multirow{2}{*}{6,008} \\
& Lisans & 215 & 3,2084 &, 69263 & \\
& Lisans üstü & 68 & 2,8118 &, 95816 & \\
Bilgilendirme & Ortaokul ve Lise & 58 & 3,3793 & 1,13675 & \\
Ofisleri & Önlisans & 47 & 2,5035 &, 93476 & \multirow{2}{*}{, 113} \\
& Lisans & 215 & 2,8062 &, 96736 & \\
& Lisans üstü & 68 & 2,6176 &, 83311 & \\
Yerel & Ortaokul ve Lise & 58 & 3,7672 &, 84145 & \\
Halk İmajı & Önlisans & 47 & 3,2500 & 1,11438 & 4,065 \\
& Lisans & 215 & 3,7047 &, 82491 & \\
\hline \multirow{4}{*}{ Şehir İmaj1 } & Lisans üstü & 68 & 3,6029 &, 79906 & \\
& Ortaokul ve Lise & 58 & 3,4828 &, 92937 & \\
& Önlisans & 47 & 3,0053 &, 96753 & 7,132 \\
& Lisans & 215 & 3,3465 &, 75793 & \\
\hline
\end{tabular}

Tablo 7 eğitim durumu değişkenine göre destinasyon imajının anlamlı farklılık gösterip göstermediğinin sonuçlarını göstermektedir. Tek yönlü varyans analizi sonucuna göre yerli turistlerin "turistik işletmeler", "bilgilendirme ofisi", "yerel halk imaj1" ve "şehir imaj1" tercihlerinde eğitim durumu değişkenine göre verilen puanların arasında anlamlı farklılıklara rastlanılmıştır.

\section{Sonuç ve Öneriler}

Ülkelerin gelişmesi ve kalkınmasında önemli bir yere sahip olan turizm endüstrisi, doğrudan veya dolaylı olarak etkilediği birçok endüstri ile birlikte ekonomik canlılığın en önemli göstergelerinden birisini oluşturmaktadır. Dolayısıyla, gerek ülkelerin gerek ise turistlerin turizme olan ilgi ve beklentileri son yıllarda önemli bir oranda artış göstermektedir.

Turistlerin farklı istek ve beklentileri ile şekillenen turizm endüstrisinin, her destinasyonun pazarlanmasında değişen tüketici isteklerine yönelik hizmet üretimi sağlamak ve turistlerin ilgisini çekecek çekiciliklere yer vermesi gerekmektedir. Böylece destinasyonların pazarlanmasında ve turistlerin destinasyona yönelik algılarında imaj önemli bir faktör olarak 
ortaya çıkmaktadır. Birçok farklı değişken tarafından etkilenebilen destinasyon imajının turistlerin beklentileri doğrultusunda sürdürülebilir şekilde sunulması gerekmektedir. Bu nedenle bölge kaynaklarının etkin olarak yönetilmesi, değerlendirilmesi ve korunması gerekmektedir.

Sözü edilen bilgiler ışığında destinasyon imajını olumlu ya da olumsuz etkileyen faktörlerin belirlenebilmesi, destinasyon imajının turistik talep üzerindeki etkilerinin anlaşılması amacıyla turistik bir destinasyon olan Kars ilini ziyaret eden ve Doğu Ekspres'i ile ayrılan yerli turistler üzerinde bir anket çalışması yapılmıştır. Kars'ı ziyaret eden yerli turistlerin destinasyon imajı hakkındaki düşünceleri belirlenmeye çalışılmıştır.

Kars'ı Doğu Ekspres'i ile ziyaret eden yerli turistlerin destinasyon imajına yönelik algıları incelendiğinde, Doğu Ekspres ile seyahat etmek ve yerel halk imajı faktörleri daha baskın konumdadır. Ceylan, Ceylan ve Yaman (2018)'ın çalışma sonucuna göre Doğu Ekspres ile seyahat etmek turistler için daha önce hiç deneyimlemedikleri bir seyahat tipini denemek, trende gün doğumunu izlemek, sosyal medyada paylaşımda bulunmak ve popüler kültürün etkisiyle ortaya çıkmaktadır. Bu çalışma sonucu da gösteriyor ki Kars ziyaretinde bulunan yerli turistlerin en çok önemsedikleri turistik aktivitelerin başında Doğu Ekspres'i deneyimi gelmektedir. Diğer taraftan yerel halk ile etkileşim içinde olmak turistlerin birçoğu için, yerel halkın günlük yaşam biçimine şahit olmak kadar yerel halkın gelenekleri, el sanatları, yemek kültürü hakkında bilgi edinme şansı verir (Frochot, 2003; Cohen ve Avieli, 2004; Kim vd., 2009). Beerli ve Martin (2004, s.659)'e göre algılanan imajı etkileyen destinasyon özellikleri arasında sosyal çevre açısından yerel halkın samimiyeti ve misafirliği önemli bir faktör olarak ortaya çıkmaktadır.

Kars'1 ziyaret eden yerli turistlerin destinasyon imaji algilarının demografik özelliklerine göre farklılık gösterip göstermediğinin belirlenmesi amacıyla yapılan t-testi ve varyans analizleri sonucuna göre cinsiyet, yaş grubu ve eğitim durumu değişkenlerine göre anlamlı farklılıklara rastlanılmıştır.

Destinasyon imajı ile "cinsiyete" yönelik yapılan t-testi analizi sonucu kadın ve erkek arasında "yerel halk" ve "şehir imajı" tercihlerinde anlamlı farklılıklara rastlanılmıştır. Söz konusu her iki ifadeye erkek katılımcıların kadın katılımcılarına oranla daha az katıldıkları gözlemlenmiştir. Destinasyon imajı ile "yaş grupları" değişkenine göre yapılan varyans analizi 
sonucu "25 yaş ve altı" yaş grubu katılımclların "turistik işletmeler", "bilgilendirme ofisleri", "Doğu Ekspres", "yerel halk imajı" ve "şehir imajı" faktörlerine daha fazla katılım gösterdikleri tespit edilmiştir. Destinasyon imajı ile "eğitim durumu" değişkenine göre yapılan varyans analizi sonucu "ortaokul ve lise" mezunu katılıcıların "turistik işletmeler", "bilgilendirme ofisleri", "yerel halk imajı" ve "şehir imajı" faktörlerine daha fazla katılım atfettikleri gözlemlenmiştir. Kıycı (2010; s.92)'nın turizmde destinasyon imajının ölçülmesi amacı ile Amasra'da yaptığı çalışma sonucu da gösteriyor ki destinasyon imajının belirlenmesinde cinsiyet, yaş grupları ve eğitim durumları arasında anlamlı farklılıklardan söz edilebilmektedir. Yaraşlı (2007)'ya göre ise destinasyon imajı ile cinsiyet değişkeni arasında anlamlı farklılıklardan söz edilebilirken, yaş ve eğitim durumu değişkeni arasında anlamlı farklılıklardan söz edilmemektedir.

Destinasyon imajının ölçülmesi ile ilgili yapılan çalışmaların birçoğu birbiri ile benzerlik gösterirken (Echtner ve Ritchie, 1993; Choi vd., 1999; Hui ve Wan, 2003; Beerli ve Martin, 2004; Chi ve Qu, 2008; Stepchenkove ve Morrison, 2008), bu çalışma ankete eklenen Doğu Ekspres'i seyahatine yönelik bir çok madde dolayısıyla farklılaşmaktadır.

Doğu Ekspres ile Kars'ı ziyaret eden yerli turistlerin büyük çoğunluğunun İstanbul $(\% 31,2)$ ve Ankara $(\% 20,4)$ 'dan geldikleri ortaya çımıştır. Yerli turistlerin daha çok uçak $(\% 53,1)$ ve tren $(\% 39,9)$ ulaşım aracının kullanılarak gelindiği araştırma sonucuna göre, Kars ile Ankara ve İstanbul arası ulaşım ağının daha aktif olduğu, böylelikle yolcuların daha çok bu illerden geldikleri sonucu çıkarılabilir. Diğer illerden katılımın düşük olarak gözlemlenmesi ile tatil destinasyonu olarak Kars'ın ulaşım imkanlarının yetersiz olması, şehrin çekicilik olarak ülkenin tamamına hitap etmesini engellediği sonucu çıkarılabilir. Kars'ın turistik bir destinasyon olarak ülkenin tamamına hitap edebilmesi için ulaşım ağının güçlendirilmesi gerekliliği önerilmektedir.

Diğer taraftan Kars'ı ilk kez ziyaret edenlerin sayısının oldukça yüksek $(\% 72,9)$ olduğu gözlemlenmiştir. Son dönemde yazılı ve görsel basında sıklıkla yer alan Doğu Ekspres deneyimi, yolcuların bir noktadan diğerine gitmek için kullanmaktan ziyade tren yolculuğunu deneyimlemek için tercih ettiği bir yolculuk türü olması bakımından Kars'ı bir turistik destinasyon olma konusunda önemli bir konuma getirmiştir. Kars'1 ilk kez ziyaret edenlerin sayısının oldukça yüksek $(\% 72,9)$ gözlemlendiği araştırma 
sonucuna göre gerek yazılı/görsel basında gerek ise sosyal medyada yer alan Doğu Ekspres ile yolculuk etmek Kars'ı ilk kez ziyaret eden yerli turistlerin sayısını arttırdığı sonucu çıkarılabilir. Buradan hareketle Kars'ı ziyaret eden turistlerin şehri tekrar ziyaret etmeleri veya ilk kez ziyaret edecek turistlerin ilgisini çekmek amaciyla sahip olduğu turistik aktivitelerinin (Ani Antik Kenti, Baltık Mimarisi, Çıldır Gölü, kayak, şehitlik ziyareti vs.) ön planda tutularak Kars ili çekici kılınabilir.

Araştırma sonucunda, turistlerin destinasyon imajı algılarına yönelik en çok önem verdikleri hususlar, Doğu Ekspres'i deneyimi ve yerel halk imajı gelmektedir. Kars'a yönelik imaj algısının olumlu yönde güçlenmesini isteyen kamu otoritelerinin yapacakları iyileştirmeler algılanan destinasyon imajının güçlenmesi açısından şehre katkı sağlayacağı düşünülebilir. Ayrıca, araştırmada bilgilendirme ofisleri konusunda katılımcıların çok memnun olmadıkları görülmektedir. Bu açıdan trenin son durağı olan Kars tren garında il turizm bilgilendirme ofisi kurulup turistlere fayda sağlanması önerilmektedir.

$\mathrm{Bu}$ araştırma ocak ve şubat ayları arasında Kars'ı ziyaret eden ve Doğu Ekspres'i ile ayrılan yerli turistler üzerinde gerçekleştirilmiştir. Analizde ortaya konulan bulgular yerli turistler ile sinırlıdır, yabancı turistler kapsam dışı tutulmaktadır. Yabancı turistlerin Kars destinasyon imajina yönelik algılarının ortaya konup karşılaştırılabilmesi amacıyla, gelecekte yabancı turistlere yönelik de çalışmalar yapılması önerilebilir. 
EXTENDED ABSTRACT

\title{
Destination Image of Kars Province and Orient Express Experience \\ *
}

\author{
Seda Derinalp Çanakçı - Tuncay Çanakçı - Erol Geçgin \\ Kafkas University
}

Destination image, the destination of the people towards qualifications that are emerging with the creation of a more integrated structure with individual perception (Choi et al., 1999, p.361). Therefore, the image of the destination can be expressed as the sum of the ideas, beliefs and impressions that people have about a destination (Hunt, 1975: Baloğlu and McCleary, 1999, p.870).

The image formation founded on some impressions that occur in the mind of the individual, this impression when viewed as the image of the destination; promotional resources (travel brochures, posters), the ideas of others (family, friends, travel agencies), media (newspapers, magazines, television, books, movies) as comes from many sources. These impressions are influenced and changed by the knowledge and experience gained during the visit of the destination (Echtner and Ritchie 2003, p.38).

Given mentioned factors Kars province in recent years in the news in the media and Kars trip that tourists means of transport to choose the Orient Express and the result of an increase in shares from this trip that does not attract the attention of tourists visiting Kars.

Except for the reasons listed above, Orient Express train, which is the last destination of Kars, has a unique view of the railway transit route and social communication between the passengers during 24-26 hours makes the journey enjoyable.

\section{Method}

This research was designed to reveal the destination image of Kars and the opinions of tourists about the Orient Express experiences through the 
domestic tourists visiting Kars and departing with the Orient Express. The data were collected with a questionnaire developed from the literature. The implementation of the survey by researchers at the date January 24 and February 12, 2018 took place during travel by Orient Express Train. During the implementation of the survey, face-to-face contact with local tourists was established. As a result of the application, a total of 388 available questionnaires were obtained. In the research, it was preferred to use sampling method which is not based on probability as sampling choice.

\section{Findings}

It was determined that of the local tourists who visited Kars and departed with the Orient Express \%51,8 were female and $48.2 \%$ were male. When the age groups of the participants were examined, it was found that the highest rate was $52.8 \%$ for the tourist 25 years old and under local tourists. $60.8 \%$ of the participants are bachelor's degree tourists. $53.1 \%$ of the local tourists used the Orient Train as a means of transportation, $72.9 \%$ visited Kars for the first time and $45.9 \%$ stayed for $1-2$ nights. When the expenditures of domestic tourists are taken into consideration, while it is seen that $36.6 \%$ is spent $501-1500 \mathrm{TL}, 36.3 \%$ is similar to $0-500 \mathrm{TL}$. Local visitors visiting Kars mostly come from Istanbul (31.2\%) and Ankara (20.4\%).

One of the most important touristic activities of the local tourists visiting Kars is the experience of the Orient Express, followed by the visit to Ani Antique City, Çıldır Lake and Baltic architecture. According to their importance, Folk Dance is the last place.

According to the results of t-test and analysis of variance, significant differences were found according to the variables of gender, age group and educational status in order to determine whether the destination image of the local tourists visiting Kars differ according to their demographic characteristics.

\section{Discussion and Conclusion}

When the perceptions of the local tourists visiting Kars with the Orient Express are examined, the factors of traveling with Orient Express and the 
image of local people are more dominant. According to the results of Ceylan et al. (2018), traveling with Orient Express is a type of travel for tourists that they have never experienced before, watching sunrise on the train, sharing on social media and influencing popular culture. As a result of this study, it is shown that the experience of Orient Express is one of the most important touristic activities of local tourists visiting Kars. On the other hand, interacting with the local community gives many tourists the chance to learn about the local people's traditions, crafts, food culture as well as witnessing the daily life of the local people (Frochot, 2003; Cohen and Avieli, 2004; Kim et al., 2009). ). According to Beerli and Martin (2004, p.659), among the destination properties affecting the perceived image, the sincerity and hospitality of the local people is an important factor in terms of social environment.

As a result of the research, the most important issues that tourists attach to the perception of destination image are the experience of the Orient Express and the image of the local people. It can be thought that the improvements to be made by the public authorities who want to strengthen the perception of image in Kars positively will contribute to the city in terms of strengthening the perceived destination image. In addition, it was seen that the participants were not very satisfied with the information offices. In this respect, it is recommended to establish a provincial tourism information office at Kars train station, which is the last stop of the train, and to provide benefits for tourists.

This research was conducted on local tourists visiting Kars between january and february and separated by the Orient Express. The findings revealed in the analysis are limited to domestic tourists and foreign tourists are excluded. In order to reveal and compare the perceptions of foreign tourists about the destination image of Kars, it may be suggested to conduct studies for foreign tourists in the future.

\section{Kaynakça / References}

Altunışık, R., Çoşkun, R., Bayraktaroğlu, S., ve Yıldırım, E. (2012). Sosyal bilimlerde araştırma yöntemleri. Sakarya: Sakarya Yayıncılık.

Baloğlu, Ş. ve McCleary, K. W., 1999. A model of destination image formation. Annals of Tourism Research. 26 (4), 868-897. 
Beerli, A. ve Martin, J. D. (2004). Tourists' characteristics and the perceived image of tourist destinations: A quantitative analysis :A case study of Lanzarote, Spain. Tourism Mana-gement, 25, 623-636.

Benli, S., ve Yenipınar, U. (2018). Yerel yiyecek deneyiminin destinasyon imajı ve destinasyon sadakat, üzerine etkisi: Mersin'i ziyaret eden yerli turistler üzerinde bir araştırma. Akademik Sosyal Araştırmalar Dergisi, 6(82), 658-685.

Ceylan, V., Ceylan, F., ve Yaman, M. (2018). 70 Yıl Sonra Gelen Değişim: Doğu Ekspresi Yolculuğunun Gastronomi Turizmi Kapsaminda Değerlendirilmesi. 1.Uluslararası Turizmde Yeni Jenerasyonlar ve Yeni Trendler Konferansi ,01-03 Kasım 2018, Sapanca, Türkiye.

Chi, C. G. Q., ve Qu, H. (2008). Examining the structural relationships of destination image, tourist satisfaction and destination loyalty: An integrated approach. Tourism Management, 29 (4), 624-636.

Choi, W. M., Chan, A. ve Wu, J. (1999). A qualitative and quantitative assessment of Hong Kong's image as a tourist destination. Tourism Management, 20, 361-365.

Cohen, E., ve Avieli, N. (2004). Food in toursim:Attraction and impediment. Annals of Tourism Research, 31(4), 755-778.

Çokluk, Ö., Şekercioğlu, G., ve Büyüköztürk, Ş. (2012). Sosyal bilimler için çok değişkenli istatistik SPSS ve LISREL uygulamaları. Ankara: Pegem Akademi.

Cooper, C., Fletcher, J., Gilbert, D., Shepherd, R. ve Wanhill, S. (1998). Tourism:Principles and practices, (2nd ed.). England: Addison- Wesley, Longman.

Davidson, R. ve Maitland, R. (1997). Tourism destinations. London: Hodder \& Stoughton.

Doğaner, S. (1998). Türkiye ulaşım sistemleri turizm ve çevre ilişkileri. Coğrafya Dergisi, 6, 1-25.

Echtner, C. M., ve Ritchie, J. B. (2003). The meaning and measurement of destination image. Journal of Tourism Studies. 14 (1), 37-48.

Frochot, I. (2003). An analysis of regional positioning and its associated food images in French tourism regional brochures. Journal of Travel and Tourism Marketing, 14(3-4), 77-96.

Hall, C. M. (2000). Tourism planning: Policies, processes, relationships. UK: Prentice Hall. 
Leiper, N., 1995. Tourism management. Melbourne: RMIT Press.

Hui, T. K. ve Wan, T. W. D. (2003). Singapore's image as a tourist destination. International Journal of Tourism Research, 5 (4), 305-313.

Hunt, J. D., 1975. Image as a factor in tourism development. Journal of Travel Research. 13 (3), 1-7.

Kalaycı, Ş. (2010). SPSS uygulamalı çok değişkenli istatistik teknikleri. Ankara: Asil Yayın Dağıtım.

Kıyc1, Ş. (2010). Bir imaj çeşidi olarak destinasyon imajı ve turizmde destinasyon imajının ölçülmesi:Amasra örneği, Yayımlanmamış Yüksek Lisans Tezi. Zonguldak Karaelmas Üniversitesi, Sosyal Bilimler Enstitüsü İşletme Anabilim Dalı, Zonguldak.

Kim, Y. G., Eves, A., ve Scarles, C. (2009). Building a model of local food consumption on trips and holidays: A grounded theory approach. International Journal of Hospitality Management, 28, 423-431.

Kim, Y. G. ve Eves, A. (2012). Construction and validation of a scale to measure tourist motivation to consume local food. Tourism Management, 33, 1458-1467.

Kim, Y. G., Eves, A. ve Scarles, C. (2013). Empirical verification of a conceptual model of local food consumption at a tourist destination. International Journal of Hospitality Management, 33, 484-489.

Kodaş, D. (2013). Yerli ziyaretçilerin yerel yiyecek tüketim güdülerinin belirlenmesi: Beypazarı örneği. Yayınlanmamış yüksek lisans tezi, Anadolu Üniversitesi Sosyal Bilimler Enstitüsü, Eskişehir.

Nakip, M. (2006). Pazarlama araştırmaları teknikler ve (Spss destekli) uygulamalar. Ankara: Seçkin Yayıncılık.

Öter, Z., ve Özdoğan, O. N. (2005). Kültür amaçlı seyahat eden turistlerde destinasyon imaji: Selçuk- Efes örneği. Anatolia Turizm Araştırmaları Dergisi, 16(2), 127-138.

Seitz, E., çev., Ertekin, A. 1990. İmaj reklamının turizm pazarlamasındaki önemi. Anatolia Turizm Araştırmaları Dergisi, 1(1), 25-26.

Stepchenkova, S. ve Morrison, A. M. (2008). Russia's destination image among American plea-sure travelers: Revisiting Echtner and Ritchie. Tourism Management, 29 (3), 548-560.

Tolungüç, A. (1992). Tanitım ve ,imaj. Anatolia Turizm Araştırmaları Dergisi, 3(22-23), 4. 
Tosun, C. ve Temizkan, R. (2004). Türkiye'nin Dış Tanıtım ve Ülke İmajında Turist Rehberlerinin Rolü. I. Balıkesir Ulusal Turizm Kongreleri Bildirileri, 15-16 Nisan, Balıkesir.

Umur, M. (2016). Destinasyon imajı ve destinasyon kişiliğinin, ziyaretçi memnuniyeti ve geleceğe yönelik ziyaretçi davranışları üzerine etkisi: Kapadokya Örneği. Kırıkkale Üniversitesi Sosyal Bilimler Dergisi, 6, 271-294.

Yaraşlı, G. Y. (2007). Destinasyon imajı ve Trabzon yöresine dönük bir çalışma. Yayınlanmamış Yüksek Lisans tezi, Başkent Üniversitesi, Sosyal Bilimler Enstitüsü, İşletme Ana Bilim Dalı, Ankara.

\section{Kaynakça Bilgisi / Citation Information}

Çanakçı-Derinalp, S., Çanakçı, T. ve Geçgin, E. (2019). Kars ilinin destinasyon imaji ve Doğu Ekspres'i deneyimi. OPUS-Uluslararası Toplum Araştırmaları Dergisi, 11(18), 1876-1896. DOI: 10.26466/opus.567950 